\title{
Significance of Urban Vegetation on Lawns Regarding the Risk of Fire
}

\author{
Jan Winkler ${ }^{1}$, Monika Malovcová ${ }^{1}$, Dana Adamcová ${ }^{2}{ }^{\oplus}$, Paweł Ogrodnik ${ }^{3}{ }^{\circledR}$, Grzegorz Pasternak ${ }^{4} \oplus^{\oplus}$, \\ David Zumr ${ }^{5}$, Marek Kosmala ${ }^{4}$, Eugeniusz Koda ${ }^{4}$ (i) and Magdalena Daria Vaverková ${ }^{2,4, *}$
}

1 Department of Plant Biology, Faculty of AgriSciences, Mendel University in Brno, Zemědělská 1, 61300 Brno, Czech Republic; winkler@mendelu.cz (J.W.); xhurajo1@node.mendelu.cz (M.M.)

2 Department of Applied and Landscape Ecology, Faculty of AgriSciences, Mendel University in Brno, Zemědělská 1, 61300 Brno, Czech Republic; dana.adamcova@mendelu.cz

3 Institute of Security Engineering, Main School of Fire Service-SGSP, Słowackiego 52/54, 01625 Warsaw, Poland; pogrodnik@sgsp.edu.pl

4 Institute of Civil Engineering, Warsaw University of Life Sciences-SGGW, Nowoursynowska 159, 02776 Warsaw, Poland; grzegorz_pasternak@sggw.edu.pl (G.P.); marek_kosmala@sggw.edu.pl (M.K.); eugeniusz_koda@sggw.edu.pl (E.K.)

5 Faculty of Civil Engineering, Czech Technical University in Prague, Thákurova 7, 16629 Prague, Czech Republic; david.zumr@fsv.cvut.cz

* Correspondence: magdalena.vaverkova@mendelu.cz

Citation: Winkler, J.; Malovcová, M.; Adamcová, D.; Ogrodnik, P.;

Pasternak, G.; Zumr, D.; Kosmala, M.; Koda, E.; Vaverková, M.D.

Significance of Urban Vegetation on Lawns Regarding the Risk of Fire. Sustainability 2021, 13, 11027. https:// doi.org/10.3390/su131911027

Academic Editor: Boris A. Portnov

Received: 8 September 2021

Accepted: 1 October 2021

Published: 5 October 2021

Publisher's Note: MDPI stays neutral with regard to jurisdictional claims in published maps and institutional affiliations.

Copyright: (c) 2021 by the authors. Licensee MDPI, Basel, Switzerland. This article is an open access article distributed under the terms and conditions of the Creative Commons Attribution (CC BY) license (https:/ / creativecommons.org/licenses/by/ $4.0 /)$.

\begin{abstract}
Urban green infrastructure significantly influences the functioning of a city and the comfort of its residents. Lawns are an essential element of public greenery. They represent a live component, and if they are lacking, of low quality, or neglected, this will cause major problems in the urban environment. The vegetation structure of urban grassy areas changes under the influence of different management methods used for their maintenance. The main goal of this study was to evaluate the species diversity of urban lawns and to determine the influence of this vegetation on factors based on the representation of the species found. Three sites with urban lawns were chosen in a built-up city area where different types of vegetation management were applied: Typical management, in which grassy areas are mowed twice a year; intensive management, in which lawns are mowed several times a year and the biomass is removed; and extensive management, in which lawns are mowed irregularly, once a year at most, and the biomass is left unevenly on the site. Extensive management and unkempt urban grassy areas represent a high risk of fire due to the presence of plant species that produce great amounts of biomass. Combined with dry and warm weather, the dead biomass can lead to outbreaks of fire. Extensive management of urban grassy areas brings some benefits, such as lower maintenance costs and increased biodiversity and bioretention. On the other hand, intensive management reduces the risk of fire and the biodiversity of the plant community. Attention should be paid to the composition of vegetative species and their functions that could threaten the safety of residents, with the risk of fire being one of them. However, the vegetation biomass of grassy areas affected by management practices is only a precondition for the risk of fire because weather and drought occurrence play important roles as well.
\end{abstract}

Keywords: urban environment; green urban infrastructure; lawns; species diversity; fire risk

\section{Introduction}

Urban green infrastructure (UGI), at both low and high levels, significantly influences the functioning of a city and the comfort of its residents. The impact of UGI includes its utilization as an element of the urban landscape and in the direct production of ecosystem services (ES), such as water management, heat reduction, species habitats, etc. [1,2]. Individual types of UGI differ in form, destination, composition, and structure [3]. Six main groups of urban ES can be distinguished: Air filtration, microclimate regulation, noise reduction, rainwater drainage, initial wastewater treatment, and recreational/cultural 
value $[4,5]$. Recently, the main problem of cities is microclimate (air pollution and urban heat) and its negative impact on human health and comfort and energy consumption [2]. Urbanization transforms the natural land cover into engineered constructions (buildings, parking lots, streets, squares, etc.), leading to increased ambient temperature, commonly known as the urban heat island effect [6].

In recent decades, an increasing number of scientific reports have focused on urban vegetation and lawns with regard to their influence on cooling down the urban environment and the potential for saving energy [7]; in spite of that, urban lawns with very high potential remain insufficiently utilized in this respect [8]. The ability of vegetation to modify the local urban microclimate differs depending on the plant community composition [9]. Lawns are a significant element of public greenery [10]. They represent a live component, and if they are lacking, of low quality, or neglected, this will cause some of the main problems of the urban environment [5]. The potential of a positive or negative influence of lawns on urban ecosystems largely depends on the management practices, which can significantly differ [11]. Intense lawn management with herbicides, fertilizers, watering, and frequent mowing is associated with high aesthetic value [12,13], but results in unfavorable ES, such as intense water usage, nutrient runoff, and low species diversity [14]. Extensive lawn management is characterized by the use of less fertilizer and less frequent mowing [15], and these lawns are often composed of spontaneous species that can represent food for pollinators [16]. The third method comprises urban grasslands with extensive management, which can become habitats for a wide range of native plant and insect species [12]. They differ significantly from low-cut lawns in both appearance and utility functions [17]. Due to the lower management costs and higher biodiversity of urban grasslands, the need to increase their contribution in urban areas is constantly growing [18]. It should be noted that this also increases their acceptance by residents of cities for these types of solutions [19]. Considering the large number of small lawns in the urban environment and the variability of the applied management practices, the study of such habitats is a perfect opportunity to explain how plant assemblages are created and how they are modified by anthropogenic perturbations regarding taxonomy and function. Moreover, it is important to understand how their floral diversity can be enhanced and how functional lawn networks can be managed in cities.

UGI is monitored and managed with the application of remote sensing (RS) and a geographic information system (GIS) [20]. Multispectral images acquired from satellites, airplanes, or unmanned aerial vehicles (UAVs) supply rich information on the vegetation state, plant condition, and fire risk. The advantages of satellite imagery include the size of the acquired images, whereas the disadvantage is the low spatial and temporal resolution in comparison to aerial photographs [21]. Monitoring plant conditions and biomass changes using RS techniques include determining the plant vegetation index, which indicates the amount of chlorophyll in the green parts of plants. Areas covered by drying vegetation, with a low vegetation index, can become flammable, which increases the risk of fire [22,23].

Excess biomass that is not removed regularly from urban green areas can cause a risk of fire, particularly when surrounded by intense residential and service development. Ground fires, as they are usually called, can be of different intensities, depending on the humidity level, meteorological conditions, vegetation type, and topography [24]. Usually, the intensity is from 1 to $5 \mathrm{~m} \cdot \mathrm{min}^{-1}$. However, in favorable conditions, such fires can reach a speed of $15 \mathrm{~m} \cdot \mathrm{min}^{-1}$. Strong winds can increase the speed at which they propagate to over $20 \mathrm{~km} \cdot \mathrm{h}^{-1}$ [25]. In the case of high wind speed, the fire front rapidly changes direction and gets out of control, becoming health- and life-threatening to people and causing damage to building objects. In ground fires, the fire itself is not high, usually reaching several centimeters to $2 \mathrm{~m}$. In such cases, the fire propagates in all directions, with the fire front moving fastest in the direction where the wind blows [26]. The fire area is usually ellipse-shaped.

During the burning of surface grass, the temperature usually reaches $400{ }^{\circ} \mathrm{C}$. However, in the case of burning trees or bushes, it can reach up to $600-800{ }^{\circ} \mathrm{C}$. There is thus a 
significant difference between the development of surface fires and crown fires because essential oils are intensely burned during crown fires. A fire moving rapidly in tree branches will not entirely burn out all the essential oils secreted from the trees under the influence of high temperatures. Essential oils thus gather in the fire zone and cause explosions when accumulated in large quantities [27]. In surface fires, only the aboveground plant biomass is burned. Such fires do not significantly influence the soil properties due to the relatively low volume of burnt plant biomass. However, when grass areas are located on soil of peat origin, the situation is different. In such areas, sub-surface fires that cause burning out of the organic soil can occur. Sub-surface fires significantly change the habitat conditions of peatlands. During such fires, the content of easily accessible forms of phosphorus and potassium rapidly increases because these elements remain in the ash. In turn, the content of easily accessible forms of nitrogen in the soil decreases because, under high temperatures, this element is transferred into a gaseous form [28]. Regardless of the type of hazard, such as grass fire, it should be emphasized that sub-surface fires are particularly dangerous due to their intensity and unpredictability and there is a need to engage large forces and resources to neutralize them.

The main goal of this study was to evaluate the species diversity in urban lawns and determine the influence of such vegetation on factors based on the representation of the species found. The specific goals included the following: (i) To determine the influence of different levels of management of grass areas on the production of biomass that is dangerous with respect to fires; (ii) to assess the risks and benefits of different levels of management of urban grass areas; and (iii) to determine the plant species that increase the risk of fires in urban lawns. To the best of our knowledge, no study has yet linked the community composition and biomass production of grass with the flammability of urban lawns.

\section{Materials and Methods}

\subsection{Characteristics of the Territory}

Trnava $\left(48^{\circ} 21^{\prime} 57.37^{\prime \prime} \mathrm{N}, 17^{\circ} 35^{\prime} 10.18^{\prime \prime} \mathrm{E}\right)$ is the capital of the Trnava region and one of the most important cities in the Slovak Republic (Figure 1). It is situated in the Danubian lowland with altitudes ranging from 135 to $180 \mathrm{~m}$ above sea level (a.s.l.). The built-up city area lies almost entirely on a plain with altitudes ranging from 140 to $145 \mathrm{~m}$ a.s.l. (Trnávka River floodplain) and from 145 to $155 \mathrm{~m}$ a.s.l. (surrounding areas).

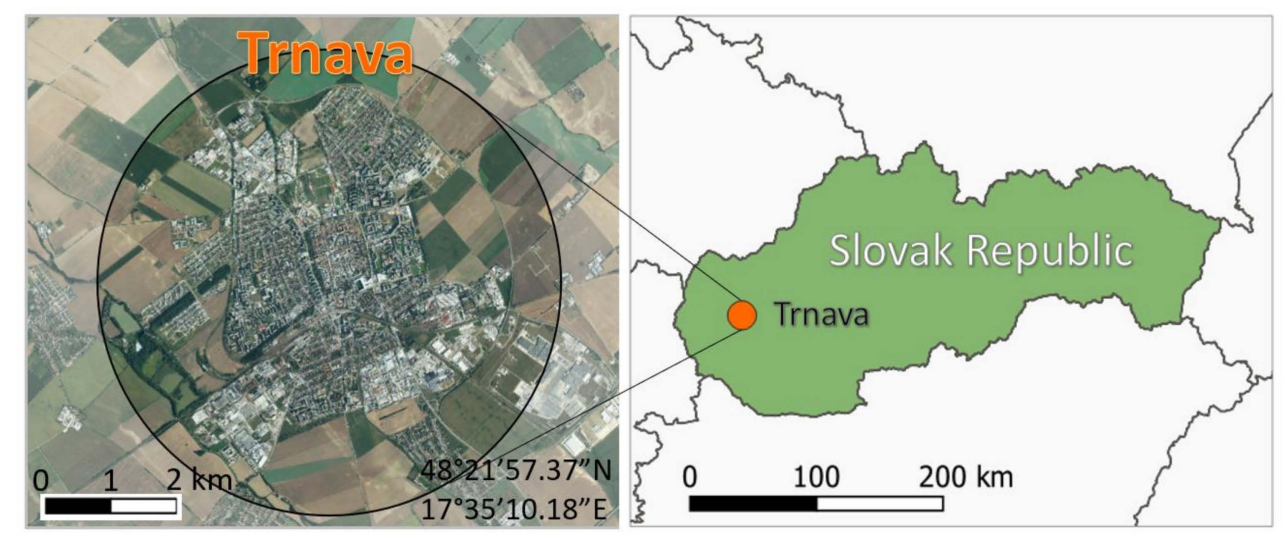

Figure 1. Trnava City location.

The city center is defined by walls on the east and west. The center directly neighbors a massively urbanized residential area, which is divided into six main city districts: Trnava Center (215 ha), Trnava East (1066 ha), Trnava North (2233 ha), Trnava West (2060 ha), Trnava South (803 ha), and Modranka (776 ha). The city covers an area of $71.54 \mathrm{~km}^{2}$, and its population is 65,596 inhabitants. It is situated in the vicinity of important European capitals such as Vienna and Budapest. Trnava is a Slovak regional capital with markedly few green 
areas. Its urban greenery and forests represent only $1.58 \%$ and $0.45 \%$, respectively, of the region (Figure 2).
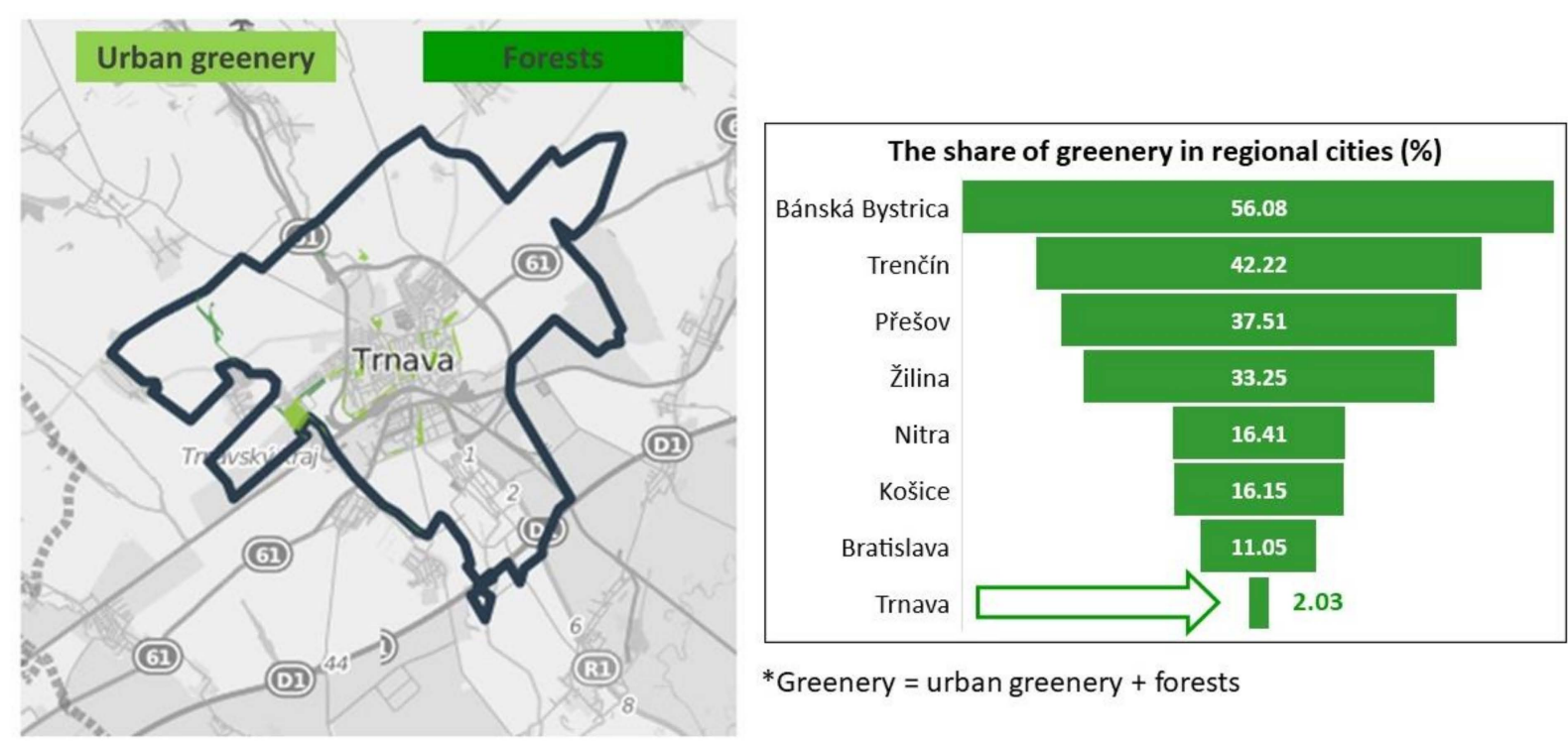

*Greenery = urban greenery + forests

Figure 2. Urban greenery and forests (\%) of Trnava; from [29].

The Trnava City cadastral area lies in a warm climatic region, characterized by a slightly dry to dry climate with mild winters, a mean annual temperature of $10.1^{\circ} \mathrm{C}$, and average total annual precipitation of $560 \mathrm{~mm}$. The average day and night temperatures for individual months of the year in the period 1855-2018 are presented in Figure 3. Daily temperatures over $20^{\circ} \mathrm{C}$ are recorded in May, June, July, August, and September.

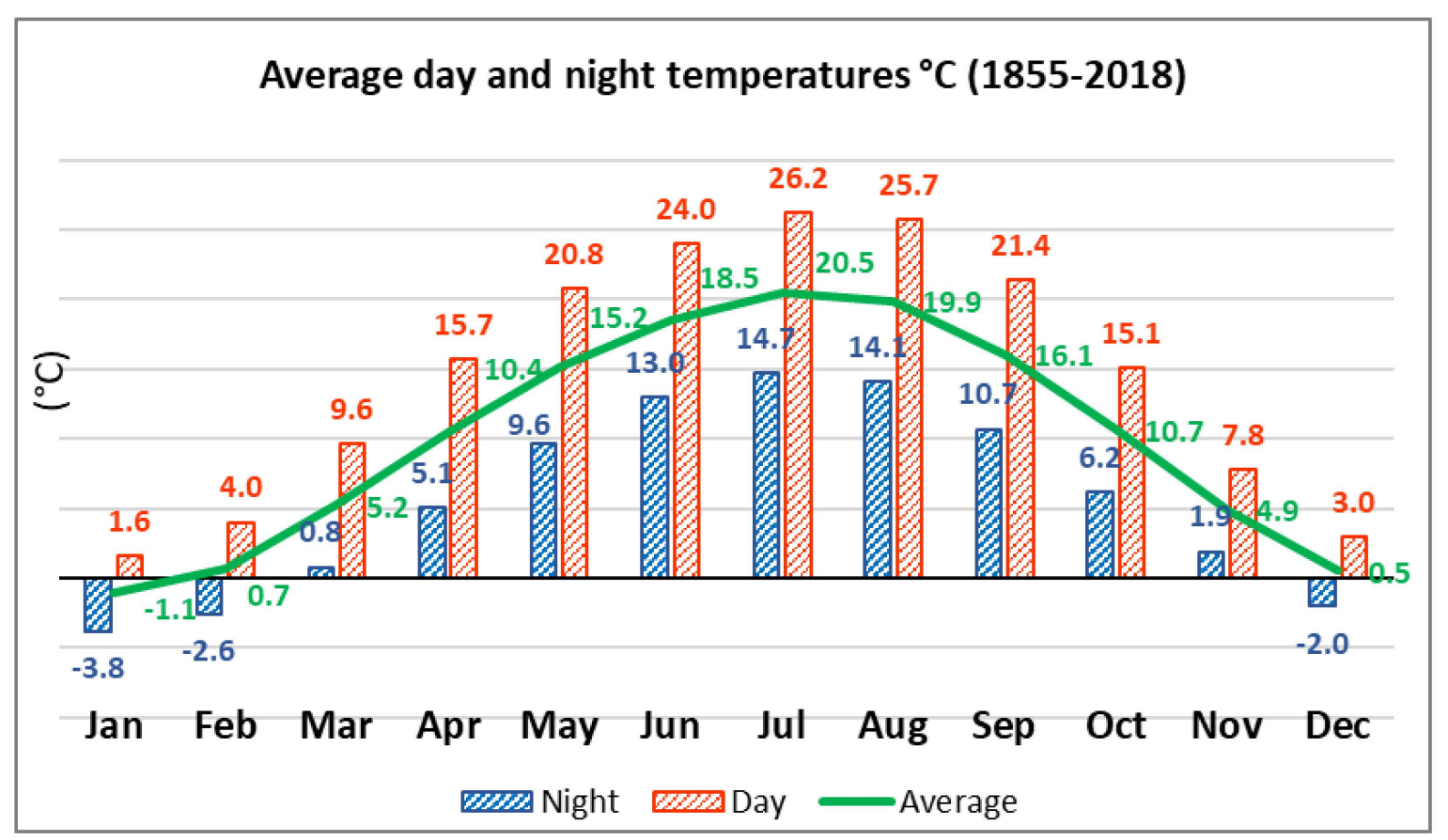

Figure 3. Average day and night temperatures in ${ }^{\circ} \mathrm{C}$ (1855-2018); from [30].

The number of summer days exceeds 50 . The highest and lowest precipitation levels have been recorded in June-August and January-March, respectively. The mean annual temperature of the active soil surface is over $12{ }^{\circ} \mathrm{C}$. The sun shines for 1800 hours per year 
on average, which is $40-45 \%$ of the maximum possible time. Snow cover occurs in Trnava for only 30-40 days per year on average, and its thickness is over $50 \mathrm{~mm}$ for only about 20 days; the average snow cover thickness is $100 \mathrm{~mm}$. NW winds prevail in the area. Other frequently occurring winds are from the SE and $\mathrm{S}$. The mean relative air humidity is about $75 \%$, with maximum (80-85\%) and minimum (66-70\%) values being recorded in winter and spring-summer, respectively.

In terms of hydrology, the Trnava City area belongs to the Váh River Basin and the Lower Dudváh watershed. In Trnava City, there are also catchments of the Parní, Trnávka, and Krupski Potok watercourses in the Little Carpathians. As for surface water, artificial water basins such as the Trnavské rybníky ponds play an important role. The small Trnávka River flows through the built-up area of Trnava City in a manmade, partly covered bed. According to the hydrogeological subdivision of Slovakia, Trnava City is situated in the Trnavská pahorkatina foothills. The mean height of the groundwater table near Trnava City is 134-145 $\mathrm{m}$ a.s.l. The chemical composition of the groundwater is characterized by high magnesium-calcium-bicarbonate concentrations.

Regarding land use, intensive agriculture in deforested areas predominates in the Trnava City cadastral area. Since the landscape is open with no massive vegetation, the soil has high erosion potential. The soil cover of Trnava City is relatively homogeneous in character, which results from the geological structure of the area, dominated by loess, on which Chernozem and Regosol soil types with high humus content developed. In terms of texture, the soils are medium heavy (loamy to sandy-loamy) and relatively insusceptible to chemical degradation (presence of carbonates), but their resistance to mechanical degradation and erosion is low. Phaeozems are common near Modranka along the Trnávka River. Hydromorphic soils are represented by Fluvisols and Gleysols. Fluvisols can be found along the Trnávka River watercourse in the south of the built-up area; the soils are light to medium heavy, with no skeleton. Clay soils occur locally in sites where the soil profile is under the long-term influence of groundwater. In the built-up area of Trnava City, anthropogenic soil types such as parks, gardens, and cemeteries occur as well.

In the past, vegetation in the Trnava City area was typically represented by various types of plant communities with high biodiversity, resulting from the geographical location, diverse geomorphology, and original hydrological conditions. The vegetation reconstruction map of climax plant communities indicates that the Trnávka River alluvia were populated mainly by ash, elm, oak, and alder alluvial forests (Ulmenion and Alnenion glutinosa-incanae). For the majority of the Trnava City area, continuous peri-Pannonian oak-hornbeam forests (Querco robori-Carpinenion betuli) and Pontic-Pannonia oak forests (Quercion pubescenti-petraeae, Quercetum petraeae-cerri) are reconstructed. In the flat part of the area, the contribution of wetlands was assumed to be much larger than today.

\subsection{Sites of Urban Lawns}

Three sites with urban lawn vegetation were selected in the built-up area, where different management types occur:

(1) Normal management: Grass areas are mowed twice a year, and biomass is taken away after the first mowing and mulched and left on the site after the second mowing. The site is part of the Na Hliny housing estate, the most recent and smallest in Trnava City. Its construction began in the 1980s and ended in the 1990s. The housing estate covers an area of 1.1 ha (GPS, 48.3883103N, 17.5972586E) (Figure 4).

(2) Intensive management: The lawn is mowed several times a year and biomass are removed. The Calvary Park site is a place of reverence, situated on an original cemetery established in 1747. The Park has interesting historical monuments, memorials of important persons, the Trnava Calvary (built on the site of the first historical Station of the Cross in the Austro-Hungarian Empire), and two massive lime trees, whose age is estimated at 260 years (GPS $48.3851289 \mathrm{~N}, 17.5774719 \mathrm{E}$ ) The housing estate covers an area of 2.1 ha (Figure 5). 
(3) Extensive management: The lawn is mowed irregularly, once a year at maximum, and biomass is left unevenly on the site, which is part of a land property with a road behind the Tesco shopping centre and in the vicinity of the Trnava water reservoir protection zone, representing an area of 5.4 ha (GPS 48.3865733N, 17.6052408E) (Figure 6).
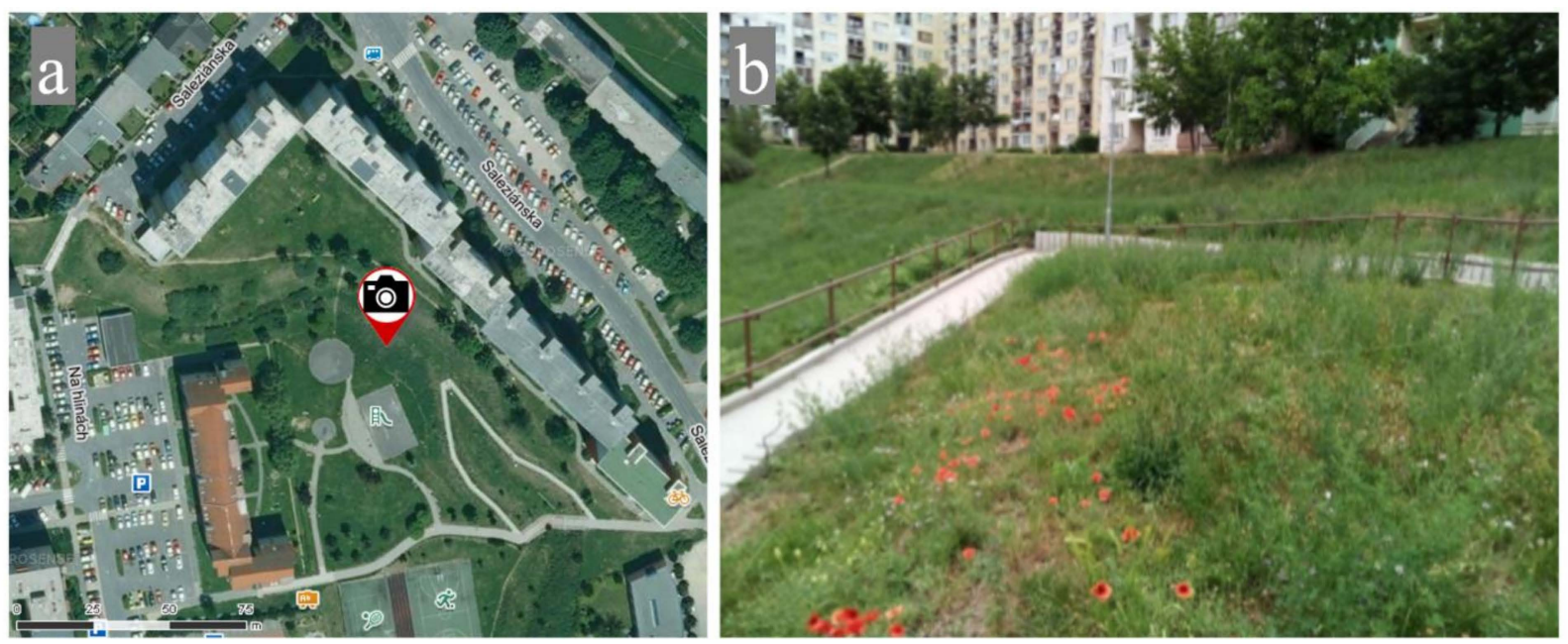

Figure 4. Sites of grassed areas with normal management: (a) Satellite image, (b) ground photo.
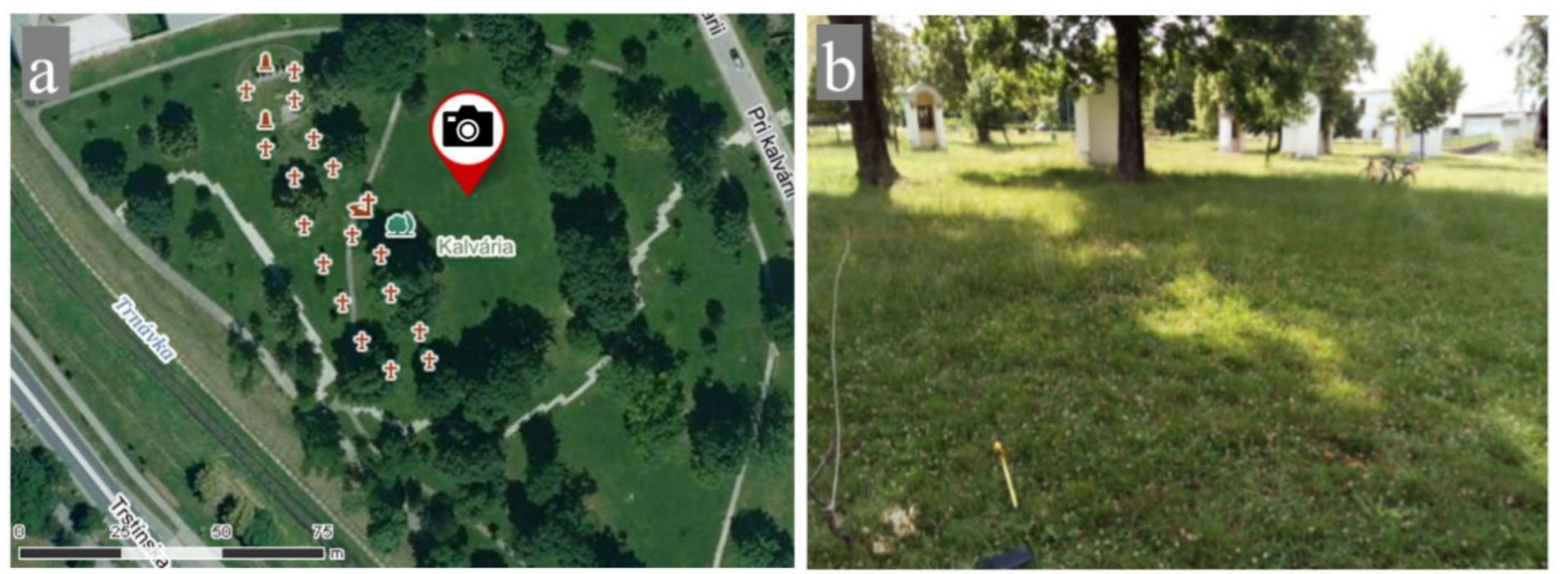

Figure 5. Sites of grassed areas with intensive management: (a) Satellite image, (b) ground photo.
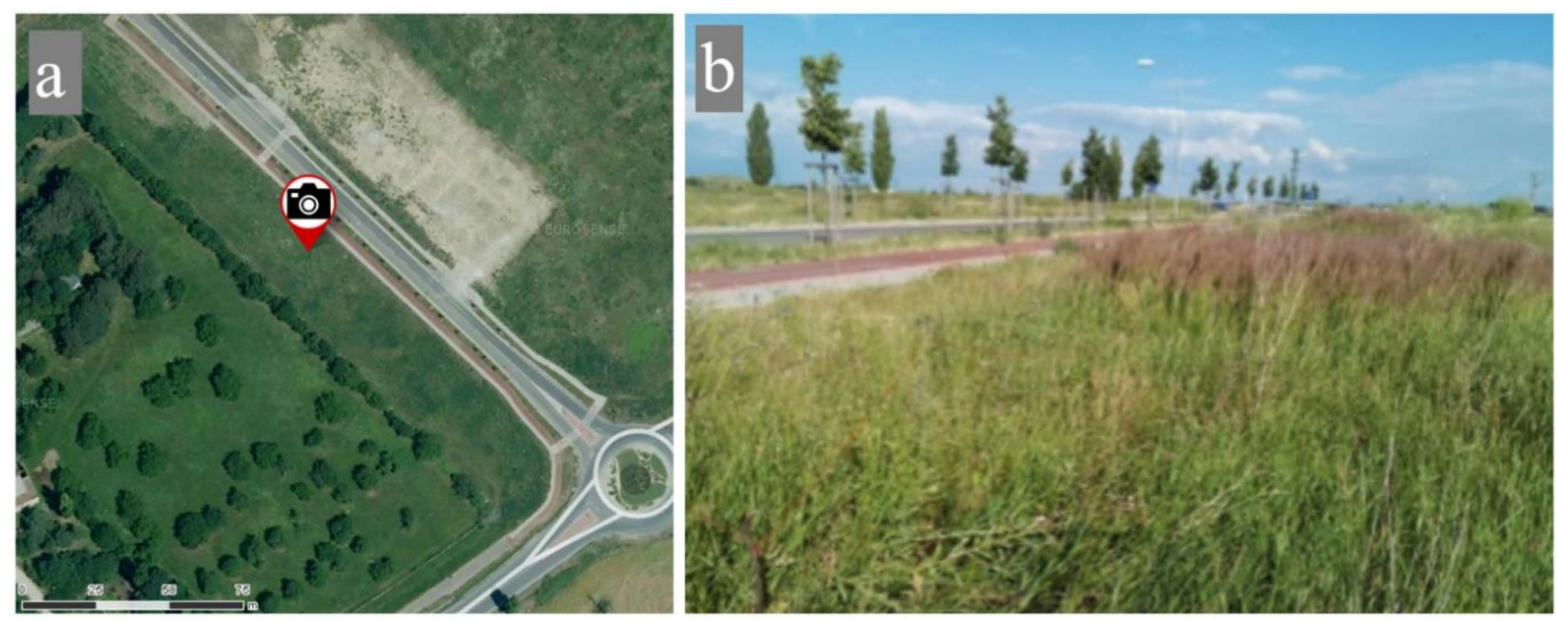

Figure 6. Sites of grassed areas with extensive management: (a) Satellite image, (b) ground photo. 


\subsection{Methodology of Vegetation Assessment}

The vegetation was assessed using the method of phytocoenological relevés, with a relevé size of $20 \mathrm{~m}^{2}$. On each site, 6 permanent plots were surveyed, on which vegetation assessment took place twice a year between 2015 and 2016 (in May and September). First, all plant taxa occurring on the permanent plot were identified, and then the cover of the aboveground biomass of individual taxa was estimated. Scientific names of individual plant species were from the database of Czech flora and vegetation [31]. Based on data from the Pladias database [31] concerning the height of the species and the determined cover, the plant species were classified into several groups according to the biomass produced. The species were also divided into groups based on the results of the CCA analysis according to the relationship with lawn management.

The values of the cover of individual plant species on the sites were processed using multidimensional analysis of ecological data. The choice of optimal analysis was governed by the gradient length determined by detrended correspondence analysis (DCA) of segments. In addition, canonical correspondence analysis (CCA) was applied. Statistical significance was established by means of the Monte Carlo test with the calculation of 999 permutations. The data were processed using Canoco 4.0. software [32]. A schematic of the experiment is presented in Figure 7.

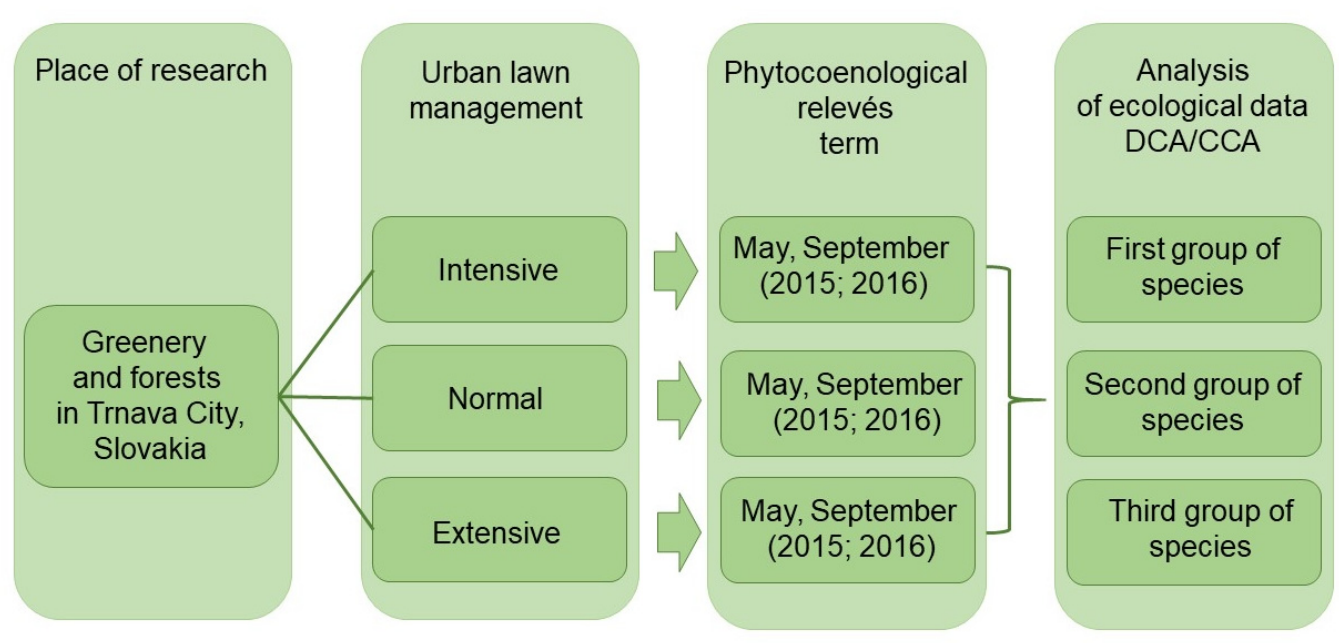

Figure 7. Schematic of experiment, showing the individual steps of the research.

\section{Results}

During the 2-year study interval, 56 plant taxa were found, 29 in the variant with normal management, 24 in the variant with intensive management, and 34 in the variant with extensive management. The representation of plant taxa in the studied sites is graphically presented in Figures 8-10.

Values of the cover of plant taxa recorded during the study were first processed using DCA. The calculated gradient length was 3.52. Then the data were further processed using CCA, which defined the spatial arrangement of individual plant species and sites with different types of lawn management. Results of the analyses are expressed graphically by means of the ordination diagram in Figure 11. 


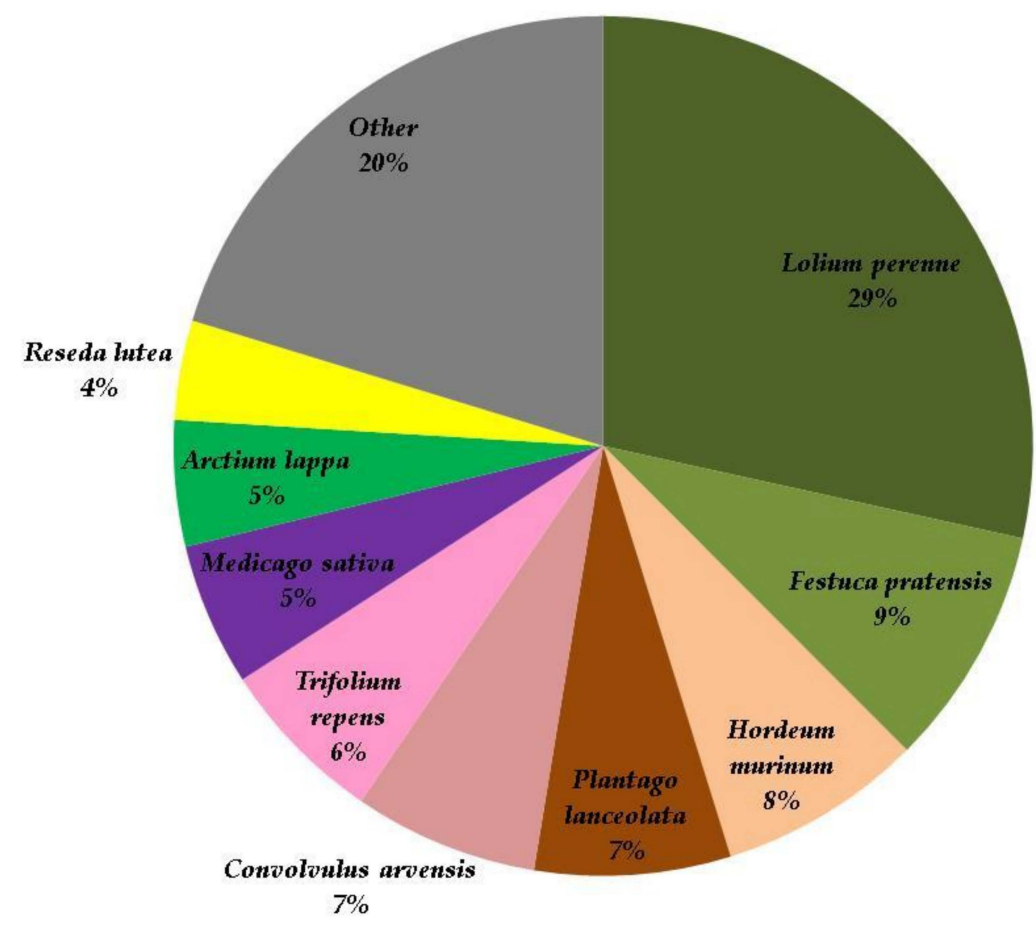

Figure 8. Species spectrum and distribution of vegetation of urban grassy areas in variant with normal management.

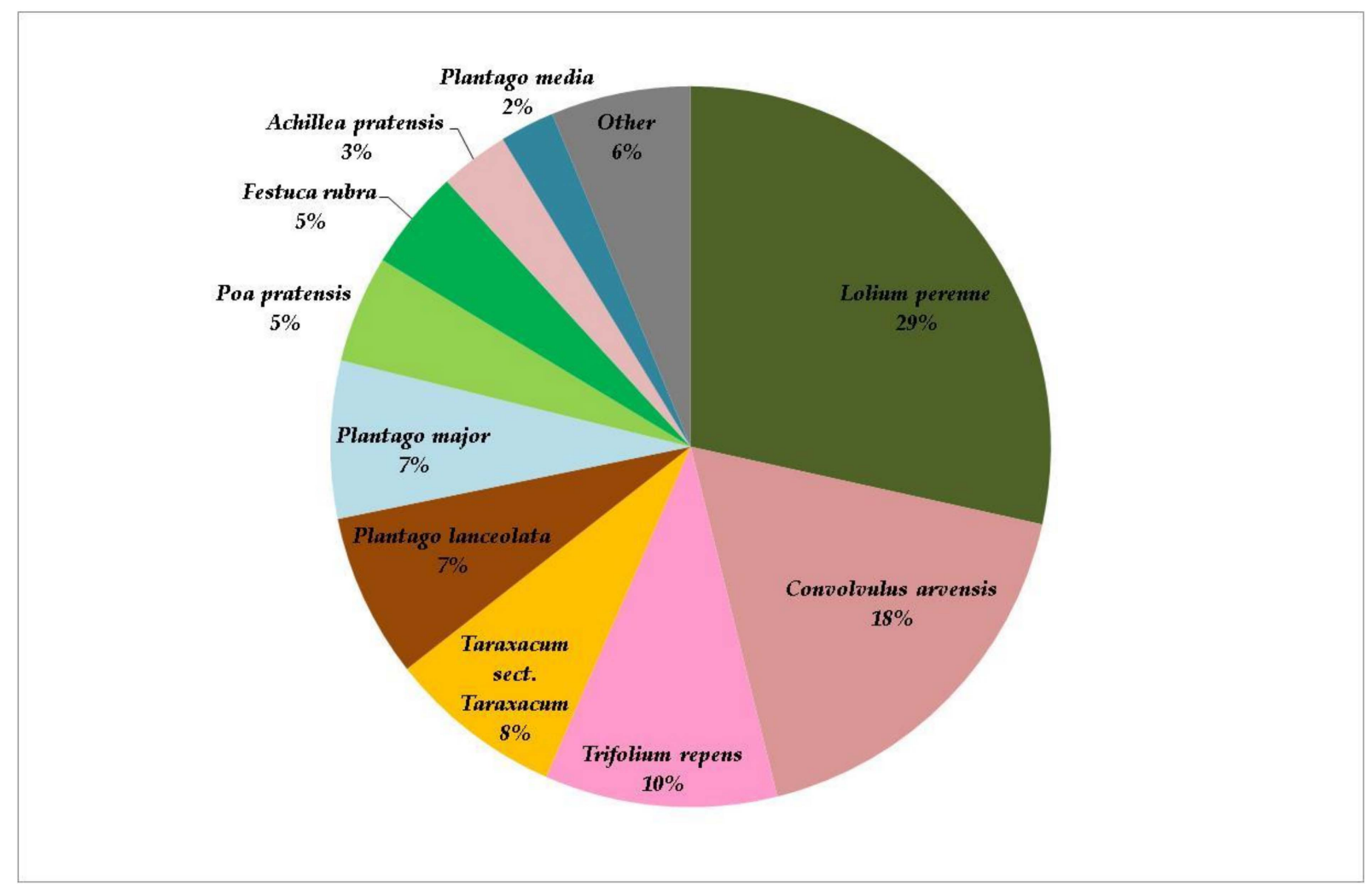

Figure 9. Species spectrum and distribution of vegetation of urban grassy areas in variant with intensive management. 


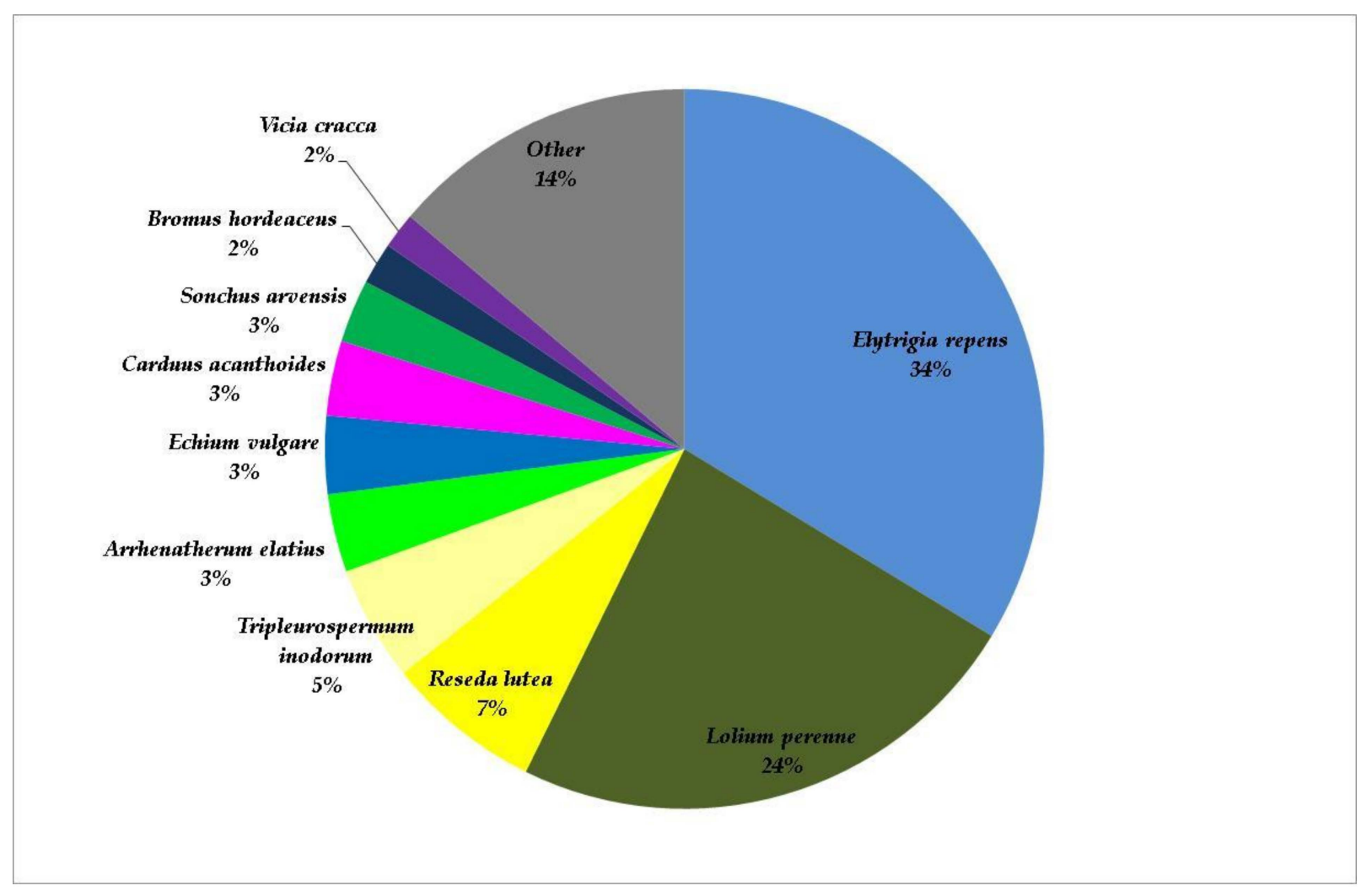

Figure 10. Species spectrum and distribution of vegetation of urban grassy areas in variant with extensive management.

Results of CCA, which were used to evaluate the cover of plant species in the years of study, were significant at a level of $\alpha=0.001$ for all canonical axes. Based on CCA, the identified taxa of plants were classified into four groups.

The first group included species that occurred primarily in the grassy areas under intensive management: Achillea pratensis, Bellis perennis, Capsela bursa-pastoris, Festuca rubra Glechoma hederacea, Plantago media, Plantago major, Poa pratensis, Taraxacum sect. Taraxacum, Trifolium arvense, and Trifolium medium.

The second group included species mainly occurring in grassy areas under normal management: Arctium lappa, Cardaria draba, Carduus acanthoides, Cichorium intybus, Convolvulus arvensis, Coronilla varia, Daucus carota, Erigeron annuus, Festuca pratensis, Hordeum murinum, Lamium purpureum, Medicago lupulina, Medicago sativa, Pastinaca sativa, Papaver rhoeas, Plantago lanceolata, Polygonum aviculare, Reseda lutea, Rumex obtusifolius, Silene latifolia, Sonchus arvensis, Trifolium pratense, and Trifolium repens.

The third group consisted of plant species occurring particularly in grassy areas under extensive management: Acer negundo, Arrhenatherum elatius, Artemisia vulgaris, Berteroa incana, Bromus hordeaceus, Echium vulgare, Elytrigia repens, Erodium cicutarium, Geranium pratense, Lepidium ruderale, Linaria vulgaris, Melilotus officinalis, Potentilla argentea, Rosa canina, Salvia pratensis, Senecio vernalis, Senecio vulgaris, Tragopogon dubius, Tripleurospermum inodorum, Vicia cracca, and Vicia tetrasperma.

The fourth group was represented by plants of the species Lolium perenne, which formed the basis of all grassy areas in all management variants. 


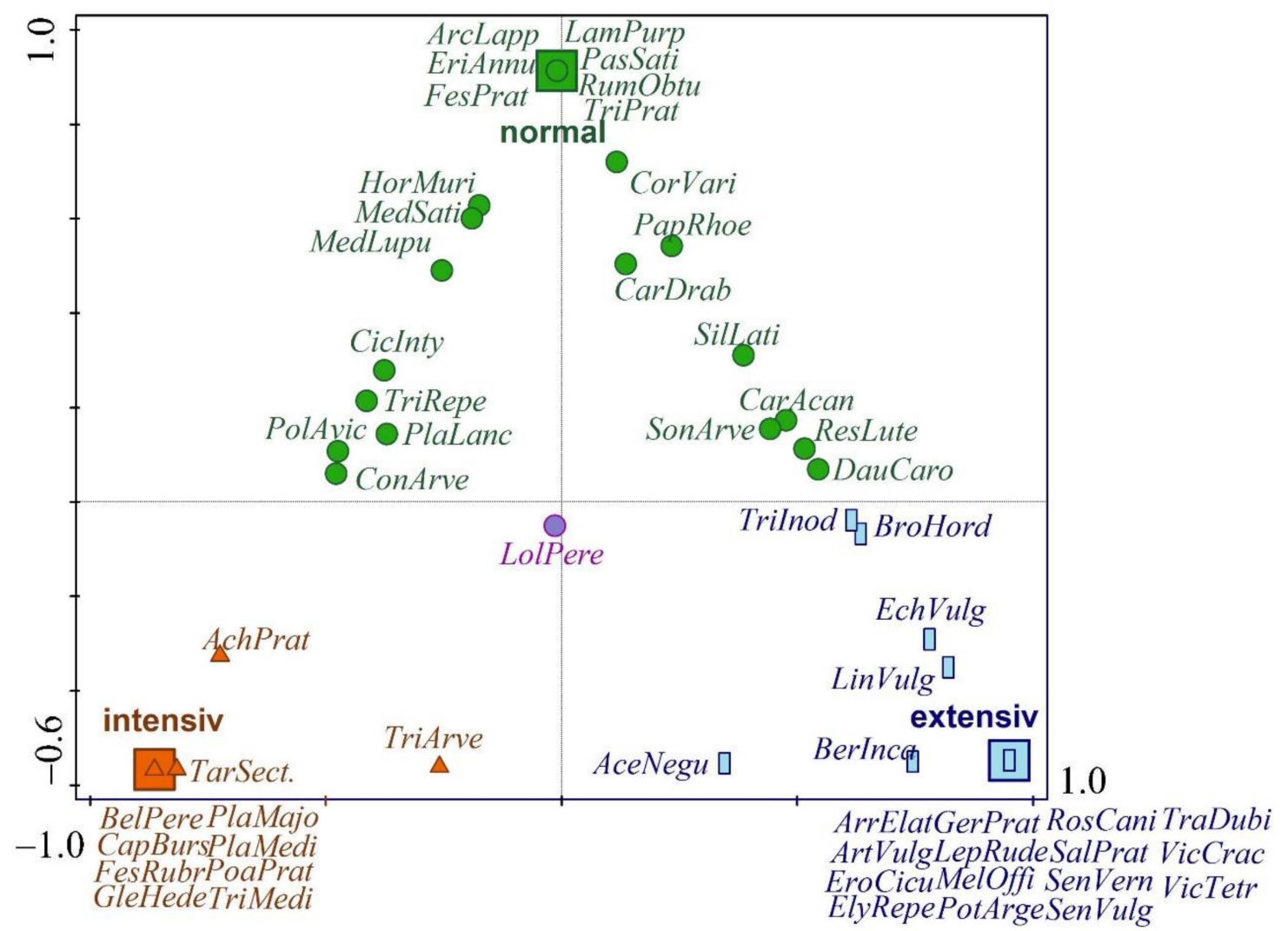

Figure 11. Reaction of plant taxa on sites with different types of management. Overall explained variability $=33.4 \%$; F-ratio $=5.3 ; p$-value $=0.001$. Intensiv, intensive management; normal, normal management; extensiv, extensive management; AceNegu, Acer negundo; AchPrat, Achillea pratensis; ArcLapp, Arctium lappa; ArrElat, Arrhenatherum elatius; ArtVulg, Artemisia vulgaris; BelPere, Bellis perennis; BerInca, Berteroa incana; BroHord, Bromus hordeaceus; CapBurs, Capsela bursa-pastoris; CarDrab, Cardaria draba; CarAcan, Carduus acanthoides; CicInty, Cichorium intybus; ConArve; Convolvulus arvensis, CorVari; Coronilla varia; DauCaro, Daucus carota; EchVulg, Echium vulgare; ElyRepe, Elytrigia repens; EriAnnu, Erigeron annuus; EroCicu, Erodium cicutarium; FesPrat, Festuca pratensis; FesRubr, Festuca rubra; GerPrat, Geranium pratense; GleHede, Glechoma hederacea; HorMuri, Hordeum murinum; LamPurp, Lamium purpureum; LepRude, Lepidium ruderale; LinVulg, Linaria vulgaris; LolPere, Lolium perenne; MedLupu, Medicago lupulina; MedSati, Medicago sativa; MelOffi, Melilotus officinalis; PasSati, Pastinaca sativa; PapRhoe, Papaver rhoeas; PlaLanc, Plantago lanceolata; PlaMedi, Plantago media; PlaMajo, Plantago major; PoaPrat, Poa pratensis; PolAvic, Polygonum aviculare; PotArge, Potentilla argentea; ResLute, Reseda lutea; RosCani, Rosa canina; RumObtu, Rumex obtusifolius; SalPrat, Salvia pratensis; SenVern, Senecio vernalis; SenVulg, Senecio vulgaris; SilLati, Silene latifolia; SonArve, Sonchus arvensis; TarSect Taraxacum sect. Taraxacum; TraDubi, Tragopogon dubius; TriArve, Trifolium arvense; TriMedi, Trifolium medium; TriPrat, Trifolium pratense; TriRepe, Trifolium repens; TriInod, Tripleurospermum inodorum; VicCrac, Vicia cracca; VicTetr, Vicia tetrasperma.

\section{Discussion}

The results show that the methods of managing urban grassy areas radically change the species composition of vegetation. Chollet et al. [8] confirmed that reduced mowing frequency offers the opportunity to switch from urban lawns to urban meadows. Changes in the vegetation structure also induce changes in the ecosystem functions of grassy areas [33]. As for the production of biomass, associated with the risk of fire are species that produce tall to medium-tall biomass (Acer negundo, Arrhenatherum elatius, Artemisia vulgaris, Bromus hordeaceus, Elytrigia repens, Hordeum murinum, Lolium perenne, Medicago sativa, Melilotus officinalis, Rosa canina). The largest share of these species was recorded in the variant under extensive management, in both the first and second terms of assessment (Figures 12 and 13), as well as in the variant under normal management, in the first term of assessment. The variant with intensive management was observed to have the smallest share of species producing biomass associated with the risk of fire. Moreover, according 
to Chollet et al. [8], low mowing frequency facilitates higher plant diversity compared to grassland with high mowing frequency. Frequent mowing facilitates the selection of species able to tolerate repeated disturbance and favors more disturbance-tolerant ruderal species. This is in line with the study of Socher et al. [34], demonstrating that mowing frequency had a stronger effect on plant species richness than fertilization.

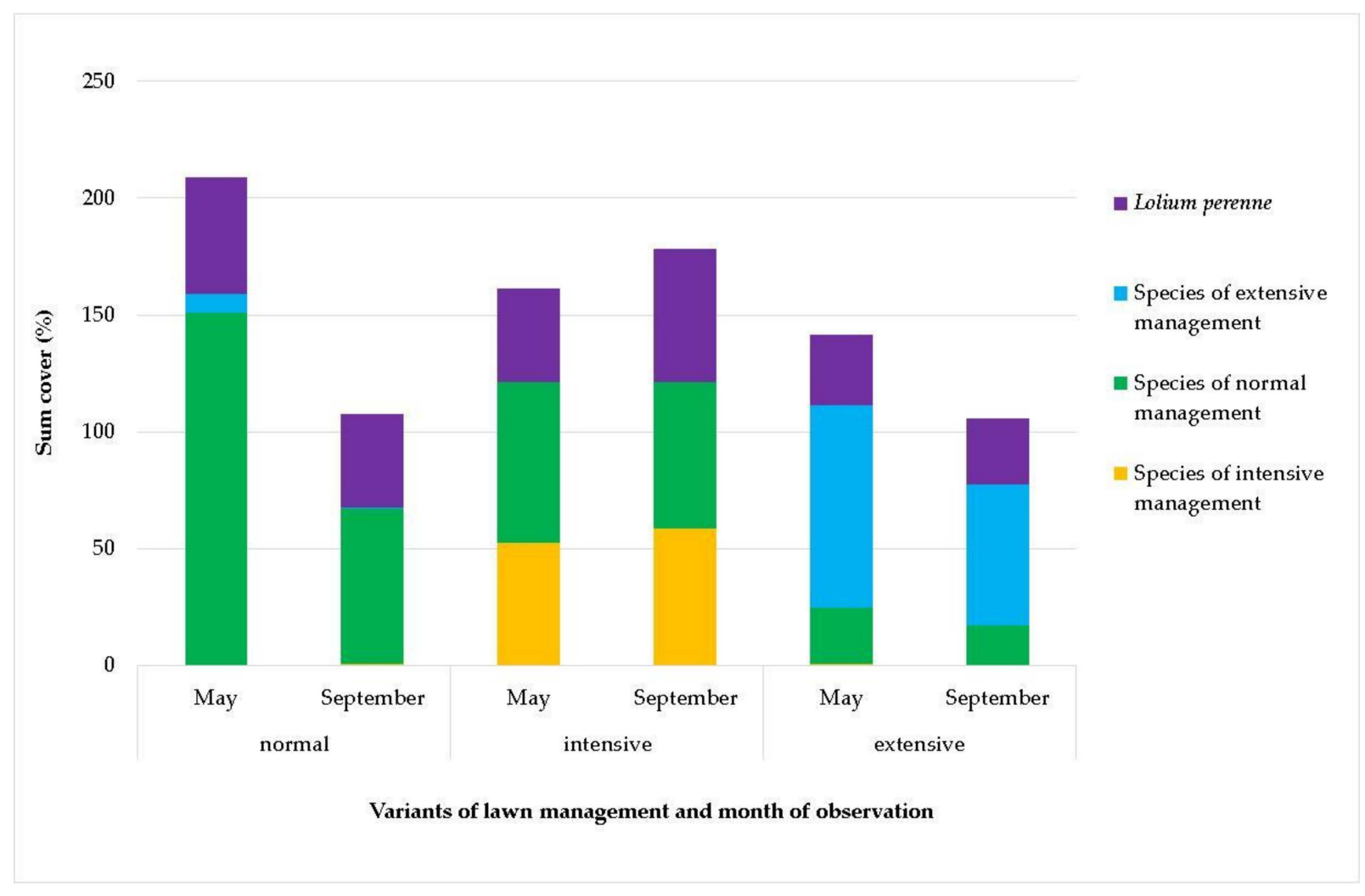

Figure 12. Representation of plant species groups according to their relation to the management of grassy areas (results of CCA).

According to Salemme et al. [35], grass was shown to increase the probability and intensity of fire by increasing loading, continuity, and flammability [36,37]. The results of this study show that the management method can alter the proportion of biomass and thus influence the risk of fire, which obviously changes over time. The risk of fire logically increases if the biomass of the vegetation of grassy areas dries out. Compared to forests, the availability of fuel is lower in grassy areas; however, this fuel is very dry [38]. Therefore, fire intensity in these areas is relatively low [39], but fires spread fast. The production of biomass over time is not identical in all plant species. Stavi [38] confirmed that the combination of large quantities of dry fuel and "suitable" meteorological conditions constitutes a "promising recipe" for fires. It should be stressed that fire seasons, due to global climate change, have altered fire seasonality (the timing of fire throughout the year) in many regions around the world [40]. If the biomass dries out at the end of spring and the beginning of summer, the share of annual winter grass species such as Bromus hordeaceus and Hordeum murinum will be particularly significant. These species are well adapted to urban ecosystems and readily spread in towns.

If the biomass dries out during the summer, the share of Arrhenatherum elatius, Elytrigia repens, and Lolium perenne will be important. These species produce great amounts of biomass [41-44]. Dead biomass of grasses forms a continuous layer [45], which is used by these species to protect themselves from unfavorable conditions (high temperature and evaporation). The dead biomass further provides a competitive advantage, preventing other plant species from accessing light. Thus, this layer of biomass plays a very important 
role in the species composition of phytocenosis [43,46,47], whereas it can become a cause of fire in urban conditions.

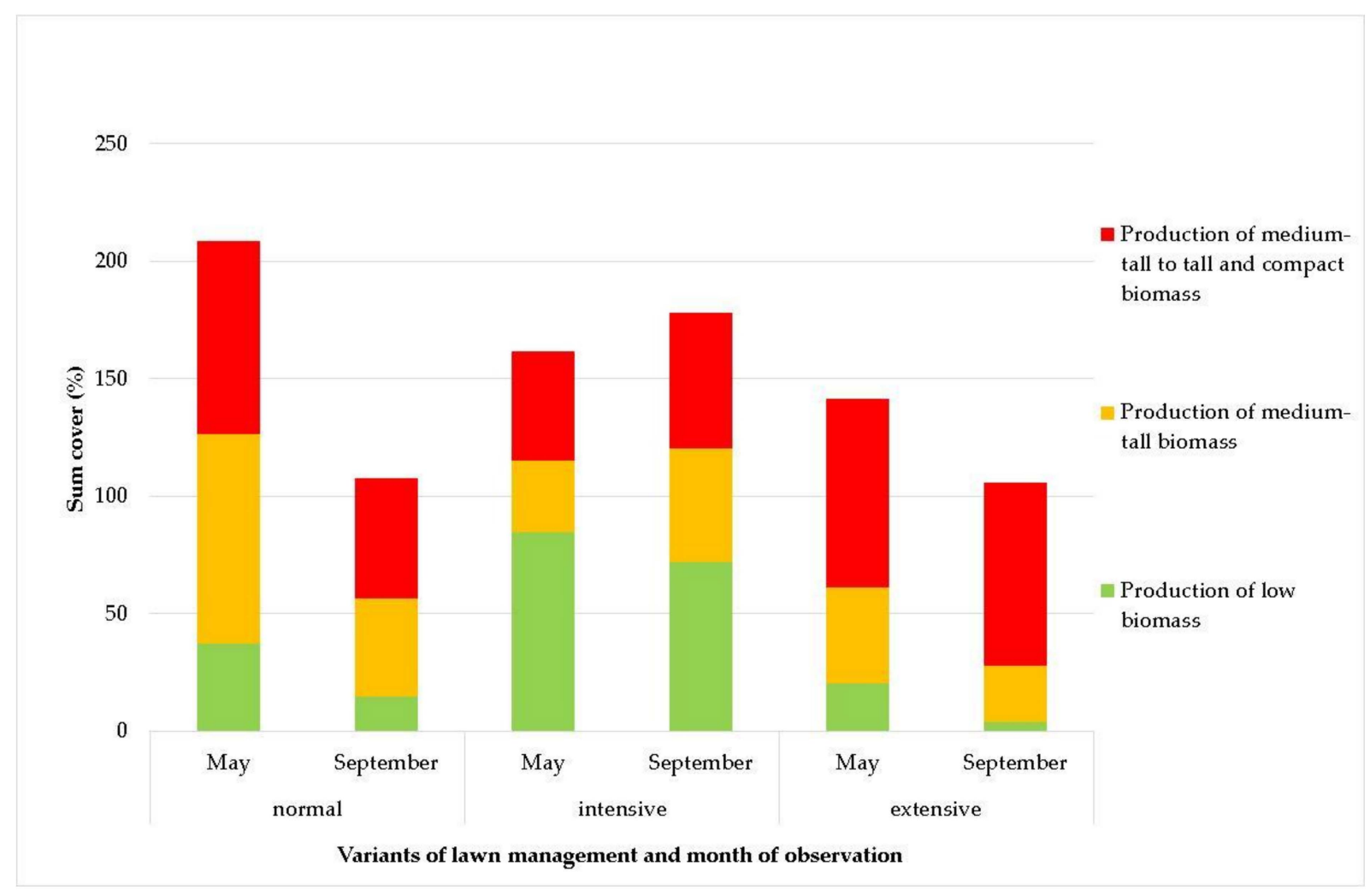

Figure 13. Representation of plant species groups according to the production of biomass important in case of fire.

If the biomass dries out toward the end of summer and at the beginning of autumn in association with the end of the growing season, fruits and seeds ripen and above-ground parts of plants gradually die. In this period, the representation of dicotyledons such as Acer negundo, Artemisia vulgaris, Medicago sativa, Melilotus officinalis, and Rosa canina is particularly important [48-50]. The biomass of these species increases the risk of fire. Acer negundo is classified as an invasive species and very often and quickly colonizes extensively maintained areas. Thanks to its rapid growth, even young Acer negundo plants pose a potential fire hazard.

Therefore, it is obvious that the presence of biomass of grassy areas affected by management practices is only a precondition for fire risk [35] because weather conditions and the occurrence of drought also play important roles [51-53]. It is commonly assumed that air temperature exceeding $24{ }^{\circ} \mathrm{C}$, relative air humidity above $40 \%$, a lack of precipitation, and a lack of clouds or low cloudiness are parameters that determine fire weather conditions [54-56], during which over $60 \%$ of plant biomass fires are produced. Biomass humidity at $30 \%$ is the boundary level, above which the development of fire from point heat sources and its propagation is rather improbable. At the same time, biomass humidity below $12 \%$ results in almost $70 \%$ of fires of all types. There is also the possibility of endogenic auto-flammability resulting from the auto-heating of material accumulated in heaps. According to various studies, the temperature of biomass auto-flammability is in the range of $150-210{ }^{\circ} \mathrm{C}$. It should be emphasized that biomass auto-flammability usually takes place when the material is accumulated in heaps.

\section{Conclusions}

Changes in climate, land use, and landscape management impact the occurrence and severity of fires particularly in Europe, where ongoing changes have strongly modified fire 
patterns over the last decades [23]. This also applies to urban areas and the management of urban green infrastructure.

The results of our study confirmed that the vegetation structure of urban grassy areas changes under the influence of different management methods used (different anthropogenic management practices). During the 2-year study interval, 56 plant taxa were found, 29 in the variant with normal management, 24 in the variant with intensive management, and 34 in the variant with extensive management. Dead biomass, which poses a high risk of fire, is an important but neglected part of ecosystem functions. Extensively managed and unkempt urban grassy areas pose a high risk of fire due to the presence of plant species that produce great volumes of biomass. Combined with dry and warm weather, dead biomass can lead to fire outbreaks. Extensive management of urban grassy areas brings benefits such as lower maintenance costs and increased biodiversity. Intensive management reduces not only the risk of fire but also plant biodiversity. Grasses are particularly important in terms of fire risk. Increased attention should be given to annual winter grass species (Bromus sp., Hordeum murinum) and perennial grass species (Arrhenatherum elatius, Poa pratensis etc.), and some of them should even be regulated. Urban grassy areas are important sources of biological diversity in cities and bring further ecosystem functions that positively influence the lives of residents. In addition, attention should also be paid to the composition and functions of plant species that could threaten the safety of people, including the risk of fire. Human activities significantly change the vegetation structure of urban grassy areas, which subsequently modifies the species composition and ecosystem functions of these areas.

Author Contributions: J.W., P.O., M.K. and M.D.V., methodology; M.M. and G.P., software; D.A., E.K. and M.D.V., validation; J.W., D.A., M.M. and P.O., formal analysis; J.W., M.M., D.Z. and M.D.V., investigation, J.W., M.M. and G.P., resources; J.W., G.P. and E.K., data curation; J.W., M.M., P.O. and M.D.V., writing — original draft preparation; D.Z., M.K. and E.K., writing—review and editing; J.W., M.M., D.A. and G.P., visualization; E.K. and M.D.V., supervision; D.Z. and M.D.V., project administration; D.Z. and M.D.V., funding acquisition. All authors have read and agreed to the published version of the manuscript.

Funding: This research was supported by the program INTER-EXCELLENCE, subprogram INTERCOST of the Ministry of Education, Youth and Sports CR, grant No. LTC20001.

Institutional Review Board Statement: Not applicable.

Informed Consent Statement: Not applicable.

Data Availability Statement: Not applicable.

Conflicts of Interest: The authors declare no conflict of interest.

\section{References}

1. Qin, Y. Urban Flooding Mitigation Techniques: A Systematic Review and Future Studies. Water 2020, 12, 3579. [CrossRef]

2. Francoeur, X.W.; Dagenais, D.; Paquette, A.; Dupras, J.; Messier, C. Complexifying the Urban Lawn Improves Heat Mitigation and Arthropod Biodiversity. Urban For. Urban Green. 2021, 60, 127007. [CrossRef]

3. Lehmann, I.; Mathey, J.; Rößler, S.; Bräuer, A.; Goldberg, V. Urban Vegetation Structure Types as a Methodological Approach for Identifying Ecosystem Services - Application to the Analysis of Micro-Climatic Effects. Ecol. Indic. 2014, 42, 58-72. [CrossRef]

4. Bolund, P.; Hunhamma, S. Ecosystem Services in Urban Areas. Ecol. Econ. 1999, 29, 293-301. [CrossRef]

5. Knot, P.; Hrabe, F.; Hejduk, S.; Skladanka, J.; Kvasnovsky, M.; Hodulikova, L.; Caslavova, I.; Horky, P. The Impacts of Different Management Practices on Botanical Composition, Quality, Colour and Growth of Urban Lawns. Urban For. Urban Green. 2017, 26, 178-183. [CrossRef]

6. Li, P.; Wang, Z.-H. Environmental Co-Benefits of Urban Greening for Mitigating Heat and Carbon Emissions. J. Environ. Manag. 2021, 293, 112963. [CrossRef] [PubMed]

7. Wang, Z.-H.; Zhao, X.; Yang, J.; Song, J. Cooling and Energy Saving Potentials of Shade Trees and Urban Lawns in a Desert City. Appl. Energy 2016, 161, 437-444. [CrossRef]

8. Chollet, S.; Brabant, C.; Tessier, S.; Jung, V. From Urban Lawns to Urban Meadows: Reduction of Mowing Frequency Increases Plant Taxonomic, Functional and Phylogenetic Diversity. Landsc. Urban Plan. 2018, 180, 121-124. [CrossRef] 
9. Gillner, S.; Vogt, J.; Tharang, A.; Dettmann, S.; Roloff, A. Role of Street Trees in Mitigating Effects of Heat and Drought at Highly Sealed Urban Sites. Landsc. Urban Plan. 2015, 143, 33-42. [CrossRef]

10. Hedblom, M.; Lindberg, F.; Vogel, E.; Wissman, J.; Ahrné, K. Estimating Urban Lawn Cover in Space and Time: Case Studies in Three Swedish Cities. Urban Ecosyst. 2017, 20, 1109-1119. [CrossRef]

11. Wheeler, M.M.; Neill, C.; Groffman, P.M.; Avolio, M.; Bettez, N.; Cavender-Bares, J.; Chowdhury, R.R.; Darling, L.; Grove, J.M.; Hall, S.; et al. Continental-Scale Homogenization of Residential Lawn Plant Communities. Landsc. Urban Plan. 2017, $165,54-63$. [CrossRef]

12. Norton, B.A.; Bending, G.; Clark, R.; Corstanje, R.; Dunnett, N.; Evans, K.L.; Grafius, D.; Gravestock, E.; Grice, S.M.; Harris, J.; et al. Urban Meadows as an Alternative to Short Mown Grassland: Effects of Composition and Height on Biodiversity. Ecol. Appl. 2019, 29, e01946. [CrossRef]

13. Yang, F.; Ignatieva, M.; Larsson, A.; Zhang, S.; Ni, N. Public Perceptions and Preferences Regarding Lawns and Their Alternatives in China: A Case Study of Xi'an. Urban For. Urban Green. 2019, 46, 126478. [CrossRef]

14. Ramer, H.; Nelson, K.C. Applying 'action situation' Concepts to Public Land managers' Perceptions of Flowering Bee Lawns in Urban Parks. Urban For. Urban Green. 2020, 53, 126711. [CrossRef]

15. Hugie, K.L.; Watkins, E. Performance of Low-Input Turfgrass Species As Affected by Mowing and Nitrogen Fertilization in Minnesota. HortScience 2016, 51, 1278-1286. [CrossRef]

16. Lerman, S.; Milam, J. Bee Fauna and Floral Abundance Within Lawn-Dominated Suburban Yards in Springfield, MA. Ann. Entomol. Soc. Am. 2016, 109, 713-723. [CrossRef] [PubMed]

17. Aronson, M.F.J.; Lepczyk, C.A.; Evans, K.L.; Goddard, M.A.; Lerman, S.B.; MacIvor, J.S. Biodiversity in the City: Key Challenges for Urban Green Space Management. Front. Ecol. Environ. 2017, 15, 189-196. [CrossRef]

18. Watson, C.J.; Carignan-Guillemette, L.; Turcotte, C.; Maire, V.; Proulx, R. Ecological and Economic Benefits of low-intensity Urban Lawn Management. J. Appl. Ecol. 2019, 57, 436-446. [CrossRef]

19. Lampinen, J.; Tuomi, M.; Fischer, L.K.; Neuenkamp, L.; Alday, J.G.; Bucharova, A.; Cancellieri, L.; Casado-Arzuaga, I.; Čeplová, N.; Cerveró, L.; et al. Acceptance of Near-Natural Greenspace Management Relates to Ecological and Socio-Cultural Assigned Values Among European Urbanites. Basic Appl. Ecol. 2021, 50, 119-131. [CrossRef]

20. Lotfata, A. Using Remote Sensing in Monitoring the Urban Green Spaces: A Case Study in Qorveh, Iran. Eur. J. Environ. Earth Sci. 2021, 2, 11-15. [CrossRef]

21. Sikorska, D.; Ciężkowski, W.; Babańczyk, P.; Chormański, J.; Sikorski, P. Intended Wilderness as a Nature-Based Solution: Status, Identification and Management of Urban Spontaneous Vegetation in Cities. Urban For. Urban Green. 2021, 62, 127155. [CrossRef]

22. Wang, J.; Rich, P.M.; Price, K.P.; Kettle, W.D. Relations Between NDVI and Tree Productivity in the Central Great Plains. Int. J. Remote Sens. 2004, 25, 3127-3138. [CrossRef]

23. Fernandez-Anez, N.; Krasovskiy, A.; Müller, M.; Vacik, H.; Baetens, J.; Hukić, E.; Solomun, M.K.; Atanassova, I.; Glushkova, M.; Bogunović, I.; et al. Current Wildland Fire Patterns and Challenges in Europe: A Synthesis of National Perspectives. Air Soil Water Res. 2021, 14, 1-19. [CrossRef]

24. Lazarus, B.E.; Germino, M.J.; Brabec, M.; Peterson, L.; Walker, R.N.; Moser, A. Post-Fire Management-Scale Trials of Bacterial Soil Amendment MB906 Show Inconsistent Control of Invasive Annual Grasses. Rangel. Ecol. Manag. 2020, 73, 741-748. [CrossRef]

25. Campos, I.; Abrantes, N. Forest Fires as Drivers of Contamination of Polycyclic Aromatic Hydrocarbons to the Terrestrial and Aquatic Ecosystems. Curr. Opin. Environ. Sci. Heal. 2021, 24, 100293. [CrossRef]

26. Ubysz, B.; Szczygieł, R. A Study on the Natural and Social Causes of Forest Fires in Poland. For. Ecol. Manag. 2006, 234, S13. [CrossRef]

27. Piwnicki, J.; Szczygieł, R.; Ubysz, B.; Kwiatkowski, M. Economic Analysis of the Functioning of the Forest Fire Protection System in Poland. For. Ecol. Manag. 2006, 234, S209. [CrossRef]

28. Marcisz, K.; Lamentowicz, M.; Galka, M.; Colombaroli, D.; Adolf, C.; Tinner, W. Responses of Vegetation and Testate Amoeba Trait Composition to Fire Disturbances in and Around a Bog in Central European Lowlands (northern Poland). Quat. Sci. Rev. 2019, 208, 129-139. [CrossRef]

29. Denník, N. Mapy Zelene Miest Slovenska: Objavte Fliačky Zelene v Betónovej Džungli. Available online: https:/ /dennikn.sk/18 9258/Mapy-Zelene-Miest-Slovenska-Objavte-Fliacky-Zelene-V-Betonovej-dzungli/ (accessed on 10 June 2021). [In Slovak]

30. Hikersbay. Available online: http://hikersbay.com/climate-conditions/slovakia/trnava/klimaticke-Podminky-V-trnava.html? Lang $=c s$ (accessed on 10 June 2021). [In Slovak]

31. PLADIAS. PLADIAS, 2020: Department of Botany and Zoology Faculty of Science Masaryk University. Database of the Czech Flora and Vegetation. 2018. Available online: https:/ / pladias.cz/En/ (accessed on 10 June 2021).

32. Ter Braak, C.J.F.; Šmilauer, P. Canoco Reference Manual and user's Guide: Software for Ordination (Version 5.0); Microcomputer Power: Ithaca, NY, USA, 2012.

33. Neary, D.G.; Ryan, K.C.; DeBano, L.F. Wildland Fire in Ecosystems: Effects of Fire on Soils and Water; General Technical Report RMRSGTR-42-Vol.4; USDA, Forest Service, Rocky Mountain Research Station: Ogden, UT, USA, 2005; p. 250.

34. Socher, S.A.; Prati, D.; Boch, S.; Müller, J.; Klaus, V.H.; Hölzel, N.; Fischer, M. Direct and Productivity-Mediated Indirect Effects of Fertilization, Mowing and Grazing on Grassland Species Richness. J. Ecol. 2012, 100, 1391-1399. [CrossRef]

35. Salemme, R.K.; Fraterrigo, J.M. Grass Invasion Reduces the Resilience of Tree Regeneration to Fire in the Central Hardwoods Region. For. Ecol. Manag. 2021, 491, 119202. [CrossRef] 
36. D'Antonio, C.; Tunison, J.; Loh, R. Variation in the Impact of Exotic Grass Fueled Fires on Species Composition across an Elevation Gradient in Hawaii. Austral. Ecol. 2000, 25, 507-522. [CrossRef]

37. Grigulis, K.; Lavorel, S.; Davies, I.D.; Dossantos, A.; Lloret, F.; Vila, M. Landscape-Scale Positive Feedbacks Between Fire and Expansion of the Large Tussock Grass, Ampelodesmos Mauritanica in Catalan Shrublands. Glob. Chang. Biol. 2005, 11, 1042-1053. [CrossRef]

38. Stavi, I. Wildfires in Grasslands and Shrublands: A Review of Impacts on Vegetation, Soil, Hydrology, and Geomorphology. Water 2019, 11, 1042. [CrossRef]

39. Bond, W. Fires, Ecological Effects of. In Encyclopedia of Biodiversity; Academic Press: Cambridge, MA, USA, 2001; Volume 2, pp. 745-753.

40. Miller, R.G.; Tangney, R.; Enright, N.J.; Fontaine, J.B.; Merritt, D.J.; Ooi, M.K.; Ruthrof, K.X.; Miller, B.P. Mechanisms of Fire Seasonality Effects on Plant Populations. Trends Ecol. Evol. 2019, 34, 1104-1117. [CrossRef]

41. Zaller, J.G.; Frank, T.; Drapela, T. Soil Sand Content Can Alter Effects of Different Taxa of Mycorrhizal Fungi on Plant Biomass Production of Grassland Species. Eur. J. Soil Biol. 2011, 47, 175-181. [CrossRef] [PubMed]

42. Hofer, D.; Suter, M.; Buchmann, N.; Lüscher, A. Severe Water Deficit Restricts Biomass Production of Lolium Perenne L. and Trifolium Repens L. And Causes Foliar Nitrogen But Not Carbohydrate Limitation. Plant Soil 2017, 421, 367-380. [CrossRef]

43. Ringselle, B.; De Cauwer, B.; Salonen, J.; Soukup, J. A Review of Non-Chemical Management of Couch Grass (Elymus repens). Agronomy 2020, 10, 1178. [CrossRef]

44. Winkler, J.; Koda, E.; Skutnik, Z.; Černý, M.; Adamcová, D.; Podlasek, A.; Vaverková, M.D. Trends in the Succession of Synanthropic Vegetation on a Reclaimed Landfill in Poland. Anthropocene 2021, 35, 100299. [CrossRef]

45. Dirks, I.; Streit, J.; Meinen, C. Above and Belowground Relative Yield Total of Clover-Ryegrass Mixtures Exceed One in Wet and Dry Years. Agriculture 2021, 11, 206. [CrossRef]

46. Wilson, M.V.; Clark, D.L. Controlling Invasive Arrhenatherum Elatius and Promoting Native Prairie Grasses through Mowing. Appl. Veg. Sci. 2001, 4, 129-138. [CrossRef]

47. Pooya, E.S.; Tehranifar, A.; Shoor, M.; Selahvarzi, Y.; Ansari, H. The Use of Native Turf Mixtures to Approach Sustainable Lawn in Urban Landscapes. Urban For. Urban Green. 2013, 12, 532-536. [CrossRef]

48. Weston, L.A.; Barney, J.N.; DiTommaso, A. A Review of the Biology and Ecology of Three Invasive Perennials in New York State: Japanese Knotweed (Polygonum cuspidatum), Mugwort (Artemisia Vulgaris) and Pale Swallow-Wort (Vincetoxicum Rossicum). Plant Soil 2005, 277, 53-69. [CrossRef]

49. Sikorska, D.; Sikorski, P.; Archiciński, P.; Chormański, J.; Hopkins, R.J. You Can't See the Woods for the Trees: Invasive Acer Negundo L. In Urban Riparian Forests Harms Biodiversity and Limits Recreation Activity. Sustainability 2019, 11, 5838. [CrossRef]

50. Rovná, K.; Ivanišová, E.; Žiarovská, J.; Ferus, P.; Terentjeva, M.; Kowalczewski, P.; Kačániová, M. Characterization of Rosa Canina Fruits Collected in Urban Areas of Slovakia. Genome Size, IPBS Profiles and Antioxidant and Antimicrobial Activities. Molecules 2020, 25, 1888. [CrossRef] [PubMed]

51. Zhang, X.; Chen, N.; Sheng, H.; Ip, C.; Yang, L.; Chen, Y.; Sang, Z.; Tadesse, T.; Lim, T.P.Y.; Rajabifard, A.; et al. Urban Drought Challenge to 2030 Sustainable Development Goals. Sci. Total. Environ. 2019, 693, 133536. [CrossRef]

52. Bo, M.; Mercalli, L.; Pognant, F.; Berro, D.C.; Clerico, M. Urban Air Pollution, Climate Change and Wildfires: The Case Study of an Extended Forest Fire Episode in Northern Italy Favoured by Drought and Warm Weather Conditions. Energy Rep. 2020, 6, 781-786. [CrossRef]

53. Ganteaume, A.; Barbero, R.; Jappiot, M.; Maillé, E. Understanding Future Changes to Fires in Southern Europe and Their Impacts on the Wildland-Urban Interface. J. Saf. Sci. Resil. 2021, 2, 20-29. [CrossRef]

54. Calheiros, T.; Nunes, J.P.; Pereira, M. Recent Evolution of Spatial and Temporal Patterns of Burnt Areas and Fire Weather Risk in the Iberian Peninsula. Agric. For. Meteorol. 2020, 287, 107923. [CrossRef]

55. Banerjee, S.; Das, D.; John, R. Grassland Vegetation and Roads Have Dominant Influence on Decadal-Scale Spatial-Temporal Patterns of Fires in a Species-Rich Protected Terai Habitat in Northeastern India. Agric. For. Meteorol. 2021, 304-305, 108411. [CrossRef]

56. Calheiros, T.; Pereira, M.; Nunes, J. Assessing Impacts of Future Climate Change on Extreme Fire Weather and Pyro-Regions in Iberian Peninsula. Sci. Total. Environ. 2021, 754, 142233. [CrossRef] 